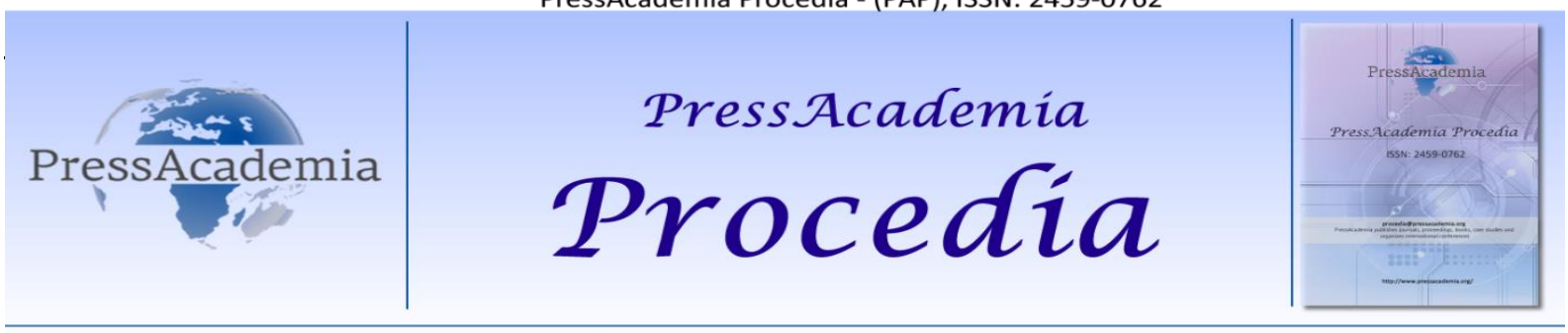

Global Business Research Congress (GBRC), May 24-25, 2017, Istanbul, Turkey.

\title{
INVESTIGATION OF THE REPORTS PREPARED BY COMPANIES WITHIN THE SCOPE OF LEGAL ARRANGEMENT
}

\author{
DOI: 10.17261/Pressacademia.2017.390 \\ PAP-GBRC-V.3-2017(5)-p.37-47 \\ Hakan Cavlak ${ }^{1}$, Yasin Cebeci ${ }^{2}$ \\ ${ }^{1}$ Marmara University, hakan.cavlak@marmara.edu.tr \\ ${ }^{2}$ Marmara University, yasin.cebeci@marmara.edu.tr
}

\section{To cite this document}

Cavlak, H. and Y. Cebeci, (2017). Investigation of the reports prepared by companies within the scope of legal arrangement. PressAcademia Procedia (PAP), V.3, p.37-47.

Permemant link to this document: $\underline{\text { http://doi.org/10.17261/Pressacademia.2017.390 }}$

Copyright: Published by PressAcademia and limited licenced re-use rights only.

\begin{abstract}
Internal and external stakeholders need a variety of information to make the right decision about the companies. This information is generally included in reports that prepared and released to the public by the companies. Reports that include both financial and nonfinancial information related to the companies are also published under different names: Independent Audit Report, Annual Report, Sustainability Report, Corporate Governance Report and Integrated Report. In this study, firstly, it was examined that the reports are prepared in which scope of legal arrangement, whether it is obligatory to publish, what institution or organization determined the information to be included in the reports and what kind of information it contains. Later, it was aimed to determine which companies in Turkey provided the relevant reports and determine the level of use of the reports.
\end{abstract}

Keywords: Report, independent audit report, annual report, sustainability report, corporate governance report and integrated report. JEL Codes: M10, M40, M48

\section{IŞLETMELER TARAFINDAN HAZIRLANAN RAPORLARIN YASAL DÜZENLEMELER KAPSAMINDA INCELENMESI}

\section{ÖZET}

İ̧̧letme içindeki ve dışındaki paydaşlar, iş̧letme hakkında doğru karar vermek için çeşitli bilgilere ihtiyaç duymaktadır. Bu bilgiler, genel olarak işletmeler tarafından hazırlanıp kamuoyuna sunulan raporlarda yer almaktadır. İşletme ile ilgili hem finansal hem de finansal olmayan bilgilerin yer aldığı raporlar da; Bağımsız Denetim Raporu, Faaliyet Raporu, Sürdürülebilirlik Raporu, Kurumsal Yönetim Raporu ve Entegre Rapor gibi farkı isimler altında yayınlanmaktadır. Bu çalışmada öncelikle söz konusu raporların hangi yasal düzenlemeler kapsamında hazırlandığı, yayınlanma zorunluluğu olup olmadığı, raporlarda yer alacak bilgilerin hangi kurum ya da kuruluş tarafından belirlendiği ve ne tür bilgiler içerdiği ele alınmıştır. Daha sonra ise ilgili raporların Türkiye'deki hangi işletmeler tarafından sunulduğunun ve raporların kullanım düzeyinin tespit edilmesi hedeflenmiştir.

Anahtar Kelimeler: Rapor, bağımsız denetim raporu, faaliyet raporu, sürdürülebilirlik raporu, kurumsal yönetim raporu ve entegre rapor. JEL Kodları: M10, M40, M48 


\section{GiRiş}

Şirketler ve şirketin tüm paydaşları, hızla değişen ticari çevrede faaliyetlerini sürdürmekte ve bu faaliyetlerini kamuoyuna çeşitli şekillerde sunmaktadırlar. Bu ise genellikle şirketlerin oluşturdukları raporlar ile gerçekleşmektedir. Raporlama süreci ve bu süreç sonucunda ortaya konan raporlar da şirketlerin karşı karşıya oldukları dinamikleri yansıtacak şekilde değişim göstermektedir. Yatıımcılar artık değere yatırım yapmakta ve iyi şirketler kendilerini tüm paydaşlara açıklamak için rakamlardan fazlasına intiyaç duymaktadırlar (Vasquez, 2014:32).

Finansal raporlar uzun yıllar boyunca şirket performansının değerlendirilmesinde kullanılan en önemli kaynak iken yaşanan küresel ekonomik krizler ve şirket skandalları, sadece finansal raporlar üzerinden yapılan değerlendirmelerin şirket performansına ve şirketin geleceğine ilişkin tüm tabloyu sunmakta yetersiz kaldığını açıkça göstermiştir. Dünyanın bir noktasında yaşanan afetlerin dünyanın diğer noktalarındaki üretimi durdurması, çevreye zarar veren uygulamaların veya insan hakları ihlallerinin geniş çaplı boykotlara yol açması, azalan doğal kaynakların hammaddeleri tehdit etmesi ve benzeri gelişmeler, finansal raporlarda yer almayan risklerin şirketler için finansal sonuçlara yol açabildiğinin göstergesi olmuştur. Bu çerçevede şirketlerin karşı karşıya olduğu çevresel, sosyal ve yönetimsel risklerin ve belirsizliklerin şirket sürdürülebilirliğini doğrudan etkilediğini gören yatırımcılar ve diğer şirket paydaşları, şirketlerden finansal olmayan performanslarına ilişkin de bilgi talep etmeye başlamışlardır (Aras ve Sarıoğlu, 2015:15). Bu durum ise şirket raporlarında ortaya konan bilgilerin çeşitlendirilmesi ile giderilmeye çalışılmaktadır.

Şirket raporlamasında yer alan bilgiler, şirketin tüm paydaşlarını ilgilendirmekle birlikte genelde yatırımcıların ihtiyaçları tarafından belirlenmektedir, ancak yatırımcıların ihtiyaçları ile şirketin diğer paydaşlarının talepleri arasında büyük bir örtüşme söz konusudur. Farklı paydaşların talep ettikleri bilgi konusunda farklı ihtiyaçları vardır, ancak teknoloji alanındaki gelişmeler ve getirilen yasal düzenlemeler ile birlikte paydaşların tam olarak istedikleri bilgiye simetrik olarak erişebilmeleri sağlanmaktadır (Illingworth, 2004:4). Son yıllarda rapor türlerinde de ortaya konan ilkeler ile beraber sunulacak bilgilerin tüm paydaşların intiyaçlarını karşılayacak düzeyde olması gerektiği belirtilmektedir. Şirketler ise bu ihtiyacı finansal bilgilere talep edilen finansal olmayan bilgileri de ekleyerek farklı kurumsal raporlar altında paydaşlarına sunmaya başlamışlardır. Bu raporlar, faaliyet, kurumsal yönetim, sürdürülebilirlik raporları ve entegre rapor isimleri ile şirket paydaşlarına sunulmaktadır.

Bu çalışmada öncelikle rapor ve raporlama ile ilgili kavramlar açıklanmıştır. Daha sonra şirketler tarafından hazırlanan raporlar çeşitli unsurlara göre türlerine ayrılmış olup şirketin kamuoyunu bilgilendirdiği rapor türlerinden Bağımsız Denetim Raporu, Faaliyet Raporu, Kurumsal Yönetim Raporu, Sürdürülebilirlik Raporu ve Entegre Rapor hakkında çeşitli bilgiler verilmiştir. Son bölümde ise BisT 30 şirketlerinin hazırladıkları raporlar, şirketlerin kurumsal internet sayfasında sundukları bilgiler çerçevesinde incelenmiş olup, analiz sonucundan elde edilen bilgiler çerçevesinde değerlendirmelerde bulunulmuştur.

\section{RAPOR VE RAPORLAMA KAVRAMLARI}

Rapor; herhangi bir işte, bir konuda yapılan inceleme, araştırma sonucunu, düşünceleri veya tespit edilenleri bildiren yazı olarak tanımlanmaktadır (TDK, 2017). Raporlama ise raporun oluşturulmasını ya da oluşturulma sürecini ifade etmektedir.

İşletmeler açısından rapor ve raporlama kavramlarına bakıldı̆ıında; raporlama sürecinin başında işletme hakkında finansal ve/veya finansal olmayan bilgiler toplanarak işlenmekte ve hazırlanış amacına göre raporlama süreci sonunda işletme içi veya dışı raporlar oluşturulmaktadır.

Raporlama uzun zamandır şirketlerin hayatının doğal bir parçası olmuştur. Bugün ise raporlama yapmak artık şirketlerin bir tercihi olmaktan çıkarak "raporla, raporlamıyorsan açıkla" (report or explain) prensibi giderek daha fazla kabul görmeye başlamıştır (Aras ve Sarıoğlu, 2015:34). Bu yüzden şirketler açısından bir zorunluluk teşkil eden raporlama, kullanıcıların intiyaçları ve beklentileri çerçevesinde düzenlenmeli, öz olmalı ve paydaşların aradığını kolayca ve net bir şekilde bulabilmesi üzerine kurgulanmalıdır (Gökten, 2016:743).

Şirketlerin sundukları raporlara genel olarak kurumsal rapor adı verilmektedir. Kurumsal raporlar, bir şirketin finansal durumunun ve/veya finansal olmayan yönünün belirli aralıklarla, basılı ve/veya elektronik olarak çeşitli iletişim vasıtaları ile paydaşlara sunulmasında kullanılan bir araçtır (Uyar, 2015:1). Bir başka tanımlama ile kurumsal raporlar; şirketlerin gönüllü veya yasal düzenlemeler gereği, kuruma özgü bilgileri, periyodik olarak çeşitli kararlara temel teşkil etmek üzere açıklanması amacına yönelik olarak düzenlenen raporlardır (Çalışkan ve Güler, 2013:61). Çeşitli isimlerle hazırlanan kurumsal raporların temel amacı ise bilgi üretmektir. Kurumsal raporlar vasıtasıyla üretilen bilgi, raporun türüne göre farklı paydaşlara karar desteği sağlamak amacıyla sunulmaktadır (Aydın, 2015:67).

Şirketlerin hesap verebilirlik ve sorumluluk yükümlülüklerinin bir parçası olarak paydaşları ile iletişim kurma aracı (FEE, 2015:7) olan kurumsal raporların hazırlanma sürecinin yönetiminden ve ortaya çıkan raporlardan sorumlu taraf, yasal düzenlemelerde de geçtiği şekildeki gibi genellikle yönetim kurulundadır. Bilginin hazırlanması ve kamuoyuna sunulması, 
genellikle yönetim kurulu üyelerinin ve üst düzey yöneticilerin sorumluluğunda olmakla birlikte bu görev işletmedeki diğer çalışanlara da devredilebilmektedir (ICAEW, 2011:3). Bahsi geçen sorumluluklar, kurumsal raporlama türlerinde değişkenlik gösterebilmektedir.

Kurumsal raporlamanın iyi bir şekilde yapılması, şirketlerin yatırımcılar ve diğer paydaşlar ile sürdürülebilir bir şekilde büyüme konusunda daha net, açık ve etkili bir şekilde iletişim kurmasına yardımcı olmaktadır (KPMG, 2013:4). Bu ise kurumsal raporların en önemli işlevlerinden bir olan dönüştürme işlevi ile sağlanmaktadır. Bu işlevde öncelikle şirketler dış paydaşlarından hiçbir geri bildirim almadan onlara raporlar aracılığı ile şirket hakkında bilgi sunmakta; karşı taraf ise bu bilgiyi alıp değerlendirmektedir. Böylece şirket paydaşları bu bilgilerden olumlu ya da olumsuz şekilde etkilenmekte, işletme hakkında eyleme geçmeye yönelmektedir. İyi yönetilen bir kurumsal raporlama süreci ile dönüştürme işlevi olumlu olarak geri dönüş sağlamakta ve paydaşlar şirkete katkı sağlayacak kararlar vererek sürdürülebilirliğe ortak olmaktadırlar (Eccles ve Serafeim, 2014:2).

\section{IŞLETMELER TARAFINDAN HAZIRLANAN RAPOR TÜRLERI}

İşletmeler tarafından hazırlanan raporlar, genel olarak kurumsal raporlar olarak adlandırılmaktadır. Kurumsal raporlar ise işletmenin dış paydaşlarına sunduğu raporları kapsamaktadır. Dış paydaşlar için hazırlanan raporlar yanında işletme içi hazırlanan raporlar da söz konusudur. Özetle işletmeler, hem işletme içi hem de işletme dışı rapor hazırlamakta ve raporun türüne göre bunları ilgililere sunmaktadırlar.

İşletme içi paydaşlara yönelik olarak hazırlanan raporlar, işletme içi gereksinimleri karşılamakta ve bu raporların sadece işletme yönetimi tarafından kullanılması öngörülmektedir (Yalkın ve Demir, 2015:156). Yönetim raporlaması olarak da adlandırılan işletme içi raporlar, finansal raporlar gibi zorunlu değil ihtiyari olarak hazırlanmakta ve bu raporlarda sunulan bilgiler tamamen işletme faaliyetlerinin planlanması ve kontrol edilmesi ile ilgili olarak iç kullanıcıların ihtiyaçlarına yönelik olarak sunulmaktadır (Çalış ve Altınsoy, 2014:30). İşletme içi hazırlanan raporlardan bazıları şunlardır: Bütçe Sorumluluk Raporları, Istisna Raporları, Çalışma Raporları, Inceleme ve Araştırma Raporları, İşveya Görev Raporları, Durum Raporları ve benzeri rapor türleri.

Günümüzde şirketler kurumsal şeffaflık kavramı çerçevesinde daha güvenilir, şeffaf ve kaliteli finansal ve finansal olmayan bilgiler sunma eğilimindedirler. Şirketlerin bu eğilimleri raporlama süreçlerine ve doğal olarak sunulan işletme dışı rapor türlerine de etki etmektedir (Sipahi ve Arsoy, 2010:51). Bu etki dolayısıyla işletme dışı raporlar bir başka ifade ile kurumsal raporlar, içerdikleri bilgilere göre de ayrıma tabi tutulabilmektedir. Bu ayrım finansal bilgiler içeren raporlar ve finansal olmayan bilgiler içeren raporlar şeklinde gerçekleşmektedir.

Şirketler, faaliyetleriyle ilgili elde ettiği sonuçları çeşitli isimlerdeki kurumsal raporlar aracılığı ile paydaşlara sunmaktadır. Bunlardan en uzun geçmişe sahip olanı finansal bilgiler içeren finansal raporlardır. Finansal raporlar, yöneticilere işletme kaynaklarının dönemler boyunca nasıl yönetildiği hakkında bilgi aktaran bir araçtır ve finansal bilgi kullanıcılarının doğru kararlar almasında önemli bir rol oynamaktadır (Palea, 2013:18). Bir başka tanımla bu raporlar, işletmenin dönem içindeki ticari faaliyetlerine göre işletmenin varlık ve yükümlülüklerine dayanarak mevcut ekonomik durumunu gösteren (Aerts ve Walton, 2013:383) ve standartlara göre hazırlanmaları durumunda da ülke dışındaki şirketler ile karşılaştırılabilir niteliğe kavuşan bir finansal dökümandır (Cebeci, 2014:161).

Finansal raporlar ile ilgili en sık karşılaşılan eleştirilerden biri; bu raporların sosyal, çevresel ve diğer kurumsal bilgileri içermemesi ile ilgilidir (Aydın, 2016:104). Bir başka açıdan finansal raporların en önemli eksiği; geçmişi raporlaması ve gelecekte oluşacak olaylara, şirketin karşı karşıya olduğu risklere, risklere karşı alınan önlemlere, şirketin vizyonu ve stratejilerine ilişkin bilgileri çok sınırlı olarak sunması hatta sunmamasından kaynaklanmaktadır. Dolayısıyla artık işletmelerin sadece finansal bilgileri sunan raporları değil, işletmenin sürdürülebilirliği ve değeri açısından finansal olmayan bilgileri de içeren raporları sunması önemli bir gerekliliktir (Yanık ve Türker, 2012:297).

Finansal bilgiler içeren raporların yanında finansal olmayan bilgileri içeren raporlar da gün geçtikçe paydaşlar tarafından talep edilmektedir. Bu doğrultuda Türkiye'de de finansal olmayan bilgiler içeren raporlar birçok başlık altında yayınlanmaktadır. Bu bilgiler; Kurumsal Yönetim Raporu, Sürdürülebilirlik Raporu ve benzeri rapor başlıkları altında veya Faaliyet Raporları içerisinde yer alan bölümlerde sunulmaktadır (TiSK, 2016:26). Söz konusu raporlardan paydaşlar açısından önem arz edenlerine ait bilgilere Türkiye'deki yasal düzenlemeler çerçevesinde çalışmanın bundan sonraki kısımlarında değinilecektir.

\subsection{Bağımsız Denetim Raporu}

Finansal bilgiler içeren finansal rapor türlerinden biri "Bağımsız Denetim Raporu" adı altında yayımlanmaktadır. Bağımsız denetim raporu, denetçinin yapmış olduğu çalışmaların içeriğini ve finansal tablolar hakkında varmış olduğu görüşünü belirttiği bir belgedir. Rapor, yazılı olarak düzenlenir ve önceden belirlenmiş bir formata sahiptir (Bozkurt, 2012:365). Bu rapor, bağımsız bir denetim şirketi tarafından hazırlanmakta olup şirketler bu raporlama sürecinde istenen bilgi ve belgeleri 
bağımsız denetim şirketine sunmakla yükümlüdürler. Bu açıdan bakıldığında bağımsız denetim raporu, şirketin kendisi tarafından hazırlanmadığı için kurumsal rapor olarak nitelendirilmemektedir.

Bağımsız denetim raporu, bağımsız denetime tabi şirketler tarafından hazırlanmak zorundadır. Bağımsız denetime tabi olacak şirketler ise Türk Ticaret Kanununun 397. Maddesine göre Bakanlar Kurulu tarafından belirlenmektedir. Bağımsız denetime tabi olacak şirketler için genel kriterler ve 2016 yılı tutarları; Aktif Toplamı (40 milyon ve üstü TL), Yılık Net Satış Hasılatı (80 milyon ve üstü TL), Çalışan Sayısı (200 ve üstü çalışan) olarak belirlenmiştir. Şirketlerin bu iki kriterden en az ikisini iki yıl üst üste sağlamaları durumunda bağımsız denetime tabi olacakları ifade edilmektedir. Ayrıca bu kriterlere bakılmaksızın, ilgili Bakanlar Kurulu Kararında belirtilen ve özel alanlarda faaliyet gösteren şirketlerin de bağımsız denetime tabi olacakları belirtilmektedir (Gökçen vd., 2016:21).

Bağımsız denetim raporunu hazırlayan bağımsız denetçi, denetimi gerçekleştirdiği süreçte Kamu Gözetimi Kurumu tarafından yayımlanan Uluslararası Denetim Standartları ile uyumlu Türkiye Denetim Standartlarını esas almaktadır (Akbulut, 2013:404). Bu standartlar ile ülkelerde Uygulanabilir Finansal Raporlama Çerçevesine göre hazırlanan finansal tabloların denetimi gerçekleştirilmektedir.

Bağımsız Denetim Standartları ve SPK tebliğleri hükümleri doğrultusunda yürütülen bir bağımsız denetim çalışması sonucunda düzenlenen bağımsız denetim raporunun içermesi gereken temel unsurlar şunlardır (Selimoğlu vd., 2015:415): Başlık, Muhatap, Giriş Paragrafı, İşletme Yönetiminin Sorumluluğu, Bağımsız Denetçinin Sorumluluğu, Bağımsız Denetçi Görüşü, Bağımsız Denetçinin Imzası, Bağımsız Denetim Raporunun Tarihi ve Bağımsız Denetim Kuruluşunun Adresi.

Bağımsız denetim raporunu hazırlayan bağımsız denetçi, raporu dört farklı görüşte sunabilir. Bunlar: Olumlu Görüş içeren Rapor, Olumsuz Görüş içeren Rapor, Görüş Vermekten (Bildirmekten) Kaçınılan Rapor ve Sınırlı Olumlu Görüş (Şartı Görüş) içeren Rapor şeklindedir (KGK, 2017:4 ve SPK, 2017). Bu görüşlerden biri bağımsız denetim faaliyeti sonucu bağımsız denetçi tarafından yazılmakta ve hazırlanan bağımsız denetim raporunda yer almaktadır.

Bağımsız denetim raporu; 6102 sayılı Türk Ticaret Kanunu, Sermaye Piyasasında Finansal Raporlamaya İlişkin Esaslar Tebliği (Seri: II, No: 14.1) ve Sermaye Piyasasında Bağımsız Denetim Standartları Hakkında Tebliğinde (Seri: X, No: 22) düzenlenmiştir. Söz konusu düzenlemeler bakanlar kurulu, KGK ve SPK tarafından yapılmıştır. Buna göre bağımsız denetim raporunu kanunda ve bakanlar kurulu kararında belirtilen şirketler ile genel olarak KAYiK'lerin sunması zorunludur. Özel sebeplerden dolayı hazırlamak isteyen şirketler ise ihtiyari olarak bağımsız denetim raporunu sunabilirler.

\subsection{Faaliyet Raporu}

Türk Ticaret Kanunu'nda faaliyet raporu ile ilgili "Yönetim kurulunun yıllık faaliyet raporu, şirketin, o yıla ait faaliyetlerinin akışı ile her yönüyle finansal durumunu, doğru, eksiksiz, dolambaçsız, gerçeğe uygun ve dürüst bir şekilde yansıtır. Bu raporda finansal durum, finansal tablolara göre değerlendirilir. Raporda ayrıca, şirketin gelişmesine ve karşılaşması muhtemel risklere de açıkça işaret olunur. Bu konulara ilişkin yönetim kurulunun değerlendirmesi de raporda yer alır." (Resmi Gazete, Sayı: 27846, 2011:m.516) ifadesi bulunmaktadır. Ayrıca kanunda, bu raporun asgari içeriğinin Gümrük ve Ticaret Bakanlığı tarafından bir yönetmelik ile düzenleneceği belirtilmektedir.

Şirketlerin Yıllık Faaliyet Raporlarının Asgari İçeriğinin Belirlenmesi Hakkında Yönetmelik'te ise faaliyet raporu; "Yönetim organı tarafından kanuna ve ilgili yönetmeliğe göre düzenlenen, şirketin ilgili yıla ilişkin faaliyetlerinin akışı ile her yönüyle finansal durumunun doğru, eksiksiz, dolambaçsız, gerçeğe uygun ve dürüst bir şekilde yansıtıldığı, şirketin gelişmesinin ve karşılaşılması muhtemel risklerin belirtildiği rapor” (Resmi Gazete, Sayı: 28395, 2012:m.3g) olarak tanımlanmaktadır.

Illgili yönetmeliğe göre faaliyet raporunun bölümleri şunlardır (Resmi Gazete, Sayı: 28395, 2012:m.7): genel bilgiler, yönetim organı üyeleri ile üst düzey yöneticilere sağlanan mali haklar, şirketin araştırma ve geliştirme çalışmaları, şirket faaliyetleri ve faaliyetlere ilişkin önemli gelişmeler, finansal durum, riskler ve yönetim organının değerlendirmesi ve diğer hususlar. Sermaye Piyasası Kurulu veya Bankacılık Düzenleme ve Denetleme Kurumu düzenlemelerine tabi şirketlerin faaliyet raporlarında, yönetmeliğe göre belirtilen bilgilerin yanında SPK ve BDDK mevzuatlarından kaynaklanan ek bilgilere de yer verilmesi gerekmektedir (Deloitte ve TKYD, 2014:4).

Yönetmelikte; finansal olmayan bilgiler olan kurumsal, çevresel ve sosyal sorumlulukların raporlanmasına ilişkin bir zorunluluk bulunmamaktadır. Ancak diğer husular başlığı altında; "yönetmelik hükümlerine aykırı olmamak kaydıyla yönetim organının uygun gördüğü ilave bilgilere de yer verilebilir" denerek işletmelere bu konuda esneklik tanınmıştır (Gençoğlu ve Aytaç, 2016:58).

Söz konusu yönetmelik, 6102 sayılı Türk Ticaret Kanunu'na göre kurulan ve faaliyet gösteren anonim, limited ve sermayesi paylara bölünmüş komandit şirketlerin yıllık faaliyet raporlarını, şirketler topluluğunda ise ana şirketin yıllık faaliyet raporunu kapsamaktadır. Bu anlamda, tüm sermaye şirketleri TTK uyarınca 2012 yılından başlayarak finansal sonuçlarını içerecek şekilde faaliyet raporu düzenlemektedir (Deloitte ve TKYD, 2014:5). Faaliyet raporunun hazırlanmasından sorumlu 
olan şirket yönetim kurulu, ilgili raporu bağımsız denetimden geçmiş finansal tabloların yardımı ve diğer konuları da içine alacak şekilde oluşturmalıdır (Akbulut, 2013:404).

Faaliyet raporu ile ilgili bir başka önemli nokta, bu raporların içinde yer alan finansal bilgilerin, denetlenen finansal tablolar ile tutarlı olup olmadığının ve gerçeği yansıtıp yansıtmadığının bağımsız denetimin kapsamı içerisinde olmasıdır. Bu kapsam doğrultusunda, bağımsız denetime tabi olduğu halde bağımsız denetimden geçmemiş yıllık faaliyet raporu düzenlenmemiş hükmündedir (Resmi Gazete, Sayı: 27846, 2011:m.397).

Özetle, faaliyet raporu; 6102 sayılı Türk Ticaret Kanunu, Şirketlerin Yıllık Faaliyet Raporlarının Asgari İçeriğine Belirlenmesi Hakkında Yönetmelik, Sermaye Piyasasında Finansal Raporlamaya Illişkin Esaslar Tebliği (Seri: XI, No: 29), Kurumsal Yönetim Illkelerinin Belirlenmesine ve Uygulanmasına İlişkin Tebliğ (Seri: IV, No: 56) ve Bankaların İzne Tabi İşlemleri ile Dolaylı Pay Sahipliğine İlişkin Yönetmelikte düzenlenmiştir. Söz konusu düzenlemeler Gümrük ve Ticaret Bakanlığı, SPK ve BDDK tarafından yapılmıştır. Bu düzenlemelere göre faaliyet raporunu tüm sermaye şirketlerinin sunması zorunludur.

\subsection{Kurumsal Yönetim Raporu}

Kurumsal yönetim, sadece işletmeye yön veren aktörler olan yönetim kurulunun ya da üst yönetimin uyacağı kurallardan oluşan değil tüm paydaşlar tarafından da uyulması gereken ilkelerden oluşan yönetim biçimi şeklinde tanımlanabilmektedir (Cavlak, 2015:5). Kurumsal yönetimin amacı, verimli bir karar alma süreci yaratmanın ve onu muhafaza etmenin yollarını arayıp bulmak, işletme stratejisinde önemli hatalar yapılmasını önlemek ve yapılan hataların da hızla düzeltilmesini güvence altına almaktır (Pound, 2002:91).Bu noktada işletmenin kurumsal yönetime ne kadar uyum sağladığının tespiti önem kazanmaktadır. Kurumsal yönetim ilkelerini uygulayan işletmeler bu ilkelere ilişkin faaliyetlerini "Kurumsal Yönetim Raporu" ile açıklamaktadırlar.

Kurumsal yönetim ilkelerinin işletmeler tarafından uygulanmasında, "uygula, uygulamıyorsan açıkla" prensibi benimsenmiştir (Doğan, 2007:104). Bu prensip doğrultusunda, yönetim kurulunun ilkelerde yer alan prensiplerin uygulanıp uygulanmadığını, uygulanmıyor ise gerekçesini ve bu ilkelerin tam olarak uyulmaması dolayısıyla meydana gelen çıkar çatışmalarına ilişkin bilgileri içeren açıklama yapması ve varsa buna ilişkin uyum raporuna, yıllık faaliyet raporunda yer vermesi gerektiği kabul edilmiştir (Resmi Gazete, 2011:m.5-6). Bu raporun ayrıca şirketlerin internet sayfalarında da yayınlanma zorunluluğu bulunmaktadır (Pamukçu, 2011:142). İşletmeler, kurumsal yönetim ilkeleri ile ilgili açıklamalara faaliyet raporlarında yer verdikleri gibi bunu ayrı bir rapor (Kurumsal Yönetim Raporu) halinde de sunabilmektedirler.

Kurumsal yönetim ile ilgili sunulan bir diğer rapor ise şirketlerin derecelendirme şirketleri tarafından kurumsal yönetim ilkelerine uyum derecelendirmesi konusundadır. Derecelendirme şirketleri, söz konusu şirketleri kurumsal yönetimin dört temel ilkesine göre çeşitli kriterler çerçevesinde değerlendirmekte ve hem bu dört ilkeye not vermekte hem de bu notların ortalamasını alarak şirketin kurumsa yönetim notunu belirlemektedirler. Ortaya çıkan sonuçlar ise şirketler tarafından özet bir şekilde kurumsal yönetim derecelendirme raporu olarak yayımlanmaktadır.

Kurumsal yönetim raporu; 6102 sayılı Türk Ticaret Kanunu, Kurumsal Yönetim Illkelerinin Belirlenmesine ve Uygulanmasına İlişkin Tebliğ (Seri: IV, No: 54 ve 56) ve Bankaların Kurumsal Yönetim İlkelerine İlişkin Yönetmelikte düzenlenmiştir. Söz konusu düzenlemeler SPK ve BDDK tarafından yapılmıştır. Buna göre kurumsal yönetim raporunu borsada faaliyet gösteren şirketlerin sunması zorunlu iken özel sebeplerden dolayı ihtiyari olarak da sunulabilir.

\subsection{Sürdürülebilirlik Raporu}

Sürdürülebilirlik raporu, bir kuruluşun çevre, toplum ve ekonomi üzerindeki olumlu veya olumsuz etkilerine ilişkin bildirimler ileten bir kurumsal raporlama türüdür. Bu raporlar, kuruluşların faaliyetlerini daha sürdürülebilir hale getirmek için hedef belirlemelerine, performanslarını ölçmelerine ve değişimi yönetmelerine yardımcı olmaktadır (GRI, 2014:3). Sürdürülebilirlik raporu, performansı yalnızca uzun vadeli kârlılık açısından ele almamakta aynı zamanda toplumun, gezegenin ve insanların refahı hakkındaki bilgileri de yansıtması bakımından da değerlendirilmektedir (Brockett ve Rezaee, 2012:27).

Küresel Raporlama Girişimi (Global Reporting Initiative, GRI), sürdürülebilirlik raporlarının hazırlanmasına öncülük eden, bu konuda kılavuz yayımlayan ve kar amacı gütmeyen bağımsız bir organizasyondur. Organizasyon, raporda yer alan bilgilerin piyasalara ve topluma yararlı ve inandırıcı hale getirilmesi için gerekli şeffaflık ve tutarlılık derecesini teşvik eden standartlaştırılmış, küresel ölçekte geçerli bir çerçeve sunmaktadır (GRI, 2014:3). Bu kapsamda kurum, 2000 yılında kılavuz olarak ilk kapsamlı sürdürülebilirlik raporlaması çerçevesini yayımlamış ve yıllar içinde güncelleyerek ilgililere sunmuştur (Aydın, 2015:70). Her güncellemesinde sektörel olarak raporlanacak alanları standardize eden GRI, halen sürdürülebilirlik raporlaması alanında neredeyse tek inisiyatif konumundadır (Gençoğlu ve Aytaç, 2016:53).

Raporun temelinde yer alan sürdürülebilirliğe ait performansın raporlanması, tüm dünyada giderek artmaktadır. Bazı şirketler sürdürülebilirlikle ilgili attıkları adımlara faaliyet raporlarında yer verirken, bazıları internet sitelerinde ayrı bir başlık açarak bu konuda paydaşlarını bilgilendirmekte, önemli bir kısmı ise ayrı bir sürdürülebilirlik raporu hazırlamaktadır (BiST, 
2014:33). Yapılan bazı değerlendirmelerde şirketlerin sürdürülebilirliğe ait bilgileri, entegre raporun bir parçası veya alt kümesi olarak da sunabileceği belirtilmektedir (PwC, 2013:4).

Türkiye'de sürdürülebilirlik raporlaması genellikle faaliyet raporlarının içinde bir bölüm olarak yer alsa da sürdürülebilirliğin ayrı bir rapor biçiminde yayınlanma anlayışı her geçen gün yaygınlaşmaktadır (Özdemir ve Pamukçu, 2016:18). Bununla birlikte Türkiye'de düzenlenen raporlarda, sürdürülebilirlik raporlaması kılavuzunda yer alan muhasebe bilgilerine az yer verildiği ve bu raporlarda sürdürülebilirlik kavramından daha çok şirket tanıtımının öne çıktığı gözlenmektedir. Bunun nedenleri arasında, sürdürülebilirlik raporlamasına yeni başlanmış olması ve muhasebe uygulamalarının alt yapısındaki eksikliklerin rolü olduğu söylenebilir (Güvemli vd., 2016:169). Bu duruma rağmen global gelişmelere paralel olarak Türkiye'de de sürdürülebilirlik raporları aracılığıyla faaliyetlerinin ekonomik, çevresel ve sosyal boyutunu kamuoyuna açıklamayı tercih eden işletme sayısı artmaktadır (Özdemir ve Pamukçu, 2016:13).

Özetle sürdürülebilirlik raporu, GRI Sürdürülebilirlik Raporlaması Kılavuzlarında düzenlenmiştir. Söz konusu düzenleme Küresel Raporlama Girişimi tarafından yapılmıştır. Türkiye'de ise herhangi bir yasal düzenleme bulunmamaktadır. Sürdürülebilirlik raporunu tüm şirketler ihtiyari olarak sunabilmektedirler.

\subsection{Entegre Rapor}

Entegre rapor, en basit ifade ile şirketlerin finansal ve finansal olmayan bilgilerinin tek bir rapor halinde sunulduğu dışsal bir rapordur (Cömert ve Kurt, 2014:1265). Bir başka açıdan ise entegre rapor; bir kuruluşun stratejisinin, kurumsal yönetiminin, performansının ve beklentilerinin kuruluşun dış çevresi bağlamında kısa, orta ve uzun vadede değer yaratmayı nasıl sağlayacağının kısa ve öz bir şekilde bildirilmesidir. Bu raporun asıl amacı, finansal sermaye sağlayan taraflara bir kuruluşun zaman içinde nasıl değer yaratacağını açıklamaktır (IIRC, 2013:7). Ayrıca entegre rapor; finansal, entelektüel, toplumsal ve çevresel sermayeyi ortak bir platforma getirme işlevini de sağlamaktadır (Katsikas vd., 2017:76).

Ekonomik ve finansal krizlerin gösterdiği raporlamadaki zayıflıklar, işletmelerin doğal çevre üzerindeki etkisi ve kaynakların uzun vadeli kullanılabilirliği konusundaki artan farkındalık, entegre raporun ortaya çıkmasına neden olan etmenlerdendir (Watson, 2012:15). Entegre rapora duyulan intiyacın bir diğer nedeni ise işletmelerin raporlarında yer alan bilgi ile yatırımcıların işletme hakkında karar vermek için ihtiyaç duydukları bilgi arasındaki farktır (Topçu ve Korkmaz, 2015:3). Bu durum ise günümüzde, yatırımcıların yatırım kararı almak için sadece finansal raporlardaki veriler ile değil, sosyal ve çevresel faktörleri de dikkate alarak işletmenin durumunu görmek ve işletmenin sürdürülebilirliğini test etmek istemelerinden kaynaklanmaktadır (Gençoğlu ve Aytaç, 2016:51).

Uluslararası Entegre Raporlama Konseyi (The International Integrated Reporting Council, IIRC), entegre raporlarının hazırlanmasına öncülük eden, bu konuda bir çerçeve yayımlayan ve düzenleyici kurumlar, yatırımcılar, şirketler, standart belirleme otoriteleri, muhasebe uzmanları ve STK'lar tarafından 2010 yılında kurulmuş küresel bir koalisyondur. IIRC, etkin bir entegre raporun, entegre düşünmeyi ve geleneksel raporlardan daha geniş bakış açılı ve ileriye dönük bir karar alma mekanizması gerektirdiğini ifade etmekte ve bu çerçevede faaliyetlerini sürdürmektedir (Aras ve Sarıoğlu, 2015:44).

Entegre rapor, kurumsal raporlamanın geldiği en ileri aşama olarak görülmekle beraber uzun bir geçmişe sahip olmaması, diğer kurumsal raporlara göre içerdiği bilgilerin geniş bir alana yayılması, uluslararası boyutta kabul gören bir standardının olmaması ve benzeri sebeplerden dolayı halen birtakım zorluklarla karşı karşıya bulunmaktadır. İnternet ve XBRL alanında işletmeler, entegre raporlarını paydaşlarına kolay, hızlı, karşılaştıılabilir bir şekilde sunmayı başarabilirlerse entegre raporun gelişimi daha rahat bir seyir izleyecektir (Eccles vd., 2015:17).

Entegre raporun, sürdürülebilirlik raporunun bir üst modeli olarak gören yaklaşımlar bulunmakla beraber aslında bu raporun, finansal raporun bir evrimi olduğunu düşünen yaklaşımlar da mevcuttur (Mio, 2016:12). Bahsi geçen görüşler doğrultusunda entegre rapor, işletmenin faaliyetlerine dair finansal raporun ve sürdürülebilirlik raporunun tek bir rapor olarak sunulduğu rapor olarak da tanımlanabilmektedir (Karğın vd., 2013:28). Bununla birlikte entegre raporun, finansal rapor ile sürdürülebilirlik raporunun birebir toplamından oluşmadığını ifade edenler de vardır. Bu yaklaşıma göre entegre rapor, sadece finansal ve finansal olmayan bilgilerin tek bir raporda bir araya getirilmesini sağlamaz, bu bilgilerin birbiriyle ve kuruluş stratejisiyle ilişkisini kurar, yaratılan değere nasıl bir katkı sağladığını gösterir (Aras ve Sarığlu, 2015:44). Her ne kadar sürdürülebilirlik raporu ile entegre raporun amaçları farklı olsa da sürdürülebilirlik raporu entegre raporun özünde bulunan bir unsurdur (GRI, 2014:85).

Özetlemek gerekirse entegre rapor, Uluslararası Entegre Raporlama Çerçevesinde düzenlenmiştir. Söz konusu düzenleme Uluslararası Entegre Raporlama Konseyi tarafından yapılmıştır. Türkiye'de ise herhangi bir yasal düzenleme bulunmamaktadır. Entegre rapor, şirketler tarafından ihtiyari olarak sunulabilmektedir. 


\section{BIST 30 ŞiRKETLERININ HAZIRLADIKLARI RAPORLAR HAKKINDA BIR ARAŞTIRMA}

\subsection{Araştırmanın Amacı, Kapsamı ve Yöntemi}

Çalışmada öncelikle Mayıs 2017 itibariyle Borsa İstanbul (BIST) 30'da yer alan şirketlerin Bağımsız Denetim Raporu, Faaliyet Raporu, Kurumsal Yönetim Raporu, Sürdürülebilirlik Raporu ve Entegre Rapordan hangilerini sunup sunmadıklarının tespit edilmesi amaçlanmıştır. Sunulan raporların hangi yıllar itibari ile sunulmaya başlandığı ve kaç şirket tarafından sunulduğunun tespit edilmesi araştırmanın diğer amaçlarını oluşturmaktadır.

Bu amaçlar doğrultusunda BIST 30 endeksinde yer alan şirketlerin kurumsal internet sitelerinden kamuoyuna sundukları raporlar temin edilerek içerik analizi yöntemi ile incelenmiştir. Bağımsız denetim raporu tüm şirketler tarafından zorunlu olarak yayınlandığından kapsam dışı bırakılmıştır.

\subsection{Araştırmanın Bulguları ve Değerlendirilmesi}

Faaliyet raporu sunan şirketlere ilişkin bilgiler Grafik 1'de gösterilmiştir. Buna göre ilk faaliyet raporu, BisT 30'daki şirketler tarafından 2000 yııında sunulmaya başlanmıştır. Söz konusu yılda 3 şirkette raporlanan faaliyet raporları yıllar itibari ile artış göstermiştir. 2016 yılına gelindiğinde ise iki şirket hariç tüm şirketlerin faaliyet raporu sundukları görülmektedir. Bu iki şirket ise özel duruma sahip olan Koza Altın İşletmeleri A.Ş. ve 2015 ve 2016 yılı faaliyet raporlarını henüz yayınlanmayan Kardemir Karabük Demir Çelik Sanayi ve Ticaret A.Ş.'dir.

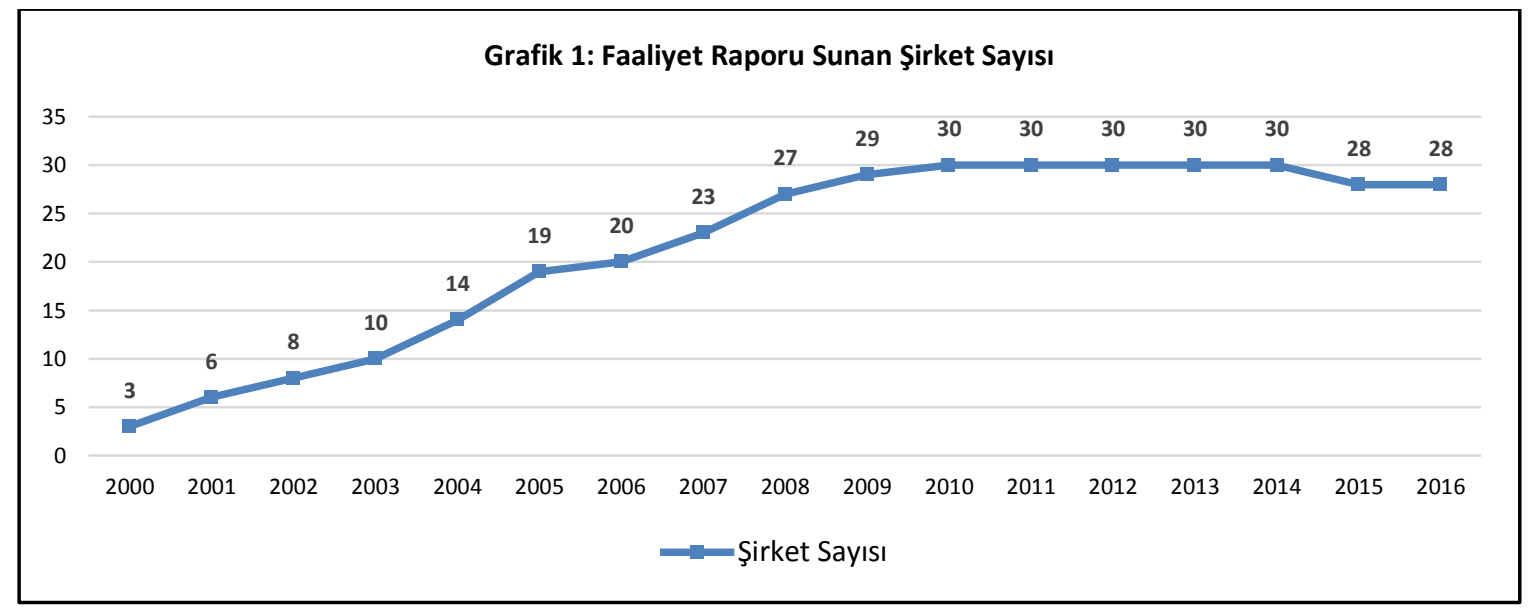

Kurumsal yönetim ile ilgili şirketler iki farklı rapor sunmaktadırlar. Bunlardan biri Kurumsal Yönetim Raporu ile diğeri ise Kurumsal Yönetim Derecelendirme Raporudur. Bazı işletmeler her iki raporu da sunarken bazıları sadece birini sunmaktadır. Grafik 2'de kurumsal yönetim raporu sunan şirketlerin sayıları gösterilmektedir. Buna göre kurumsal yönetim raporları 2004 yılından itibaren sunulmaya başlanmıştır. 2004 yılında 3 şirket ile başlayıp artarak devam eden kurumsal yönetim raporu sunumu 2015 yılında gelindiğinde 20 şirket tarafından sunulduğu tespit edilmiştir. 2016 yılında ise 14 şirket kurumsal yönetim raporunu sunsa da çalışmanın yapıldığı tarih göz önüne alındığında diğer şirketlerin de raporlarını ilerleyen günlerde sunacağı düşünülmektedir. Ayrıca borsa şirketleri için kurumsal yönetim açıklamaları zorunlu olarak gözükmesine rağmen BIST 30'da kurumsal yönetim raporu hazırlamayan şirketlerin olmasının nedeni bu şirketlerin kurumsal yönetim açıklamalarına faaliyet raporları içinde yer vermesinden kaynaklanmaktadır. 


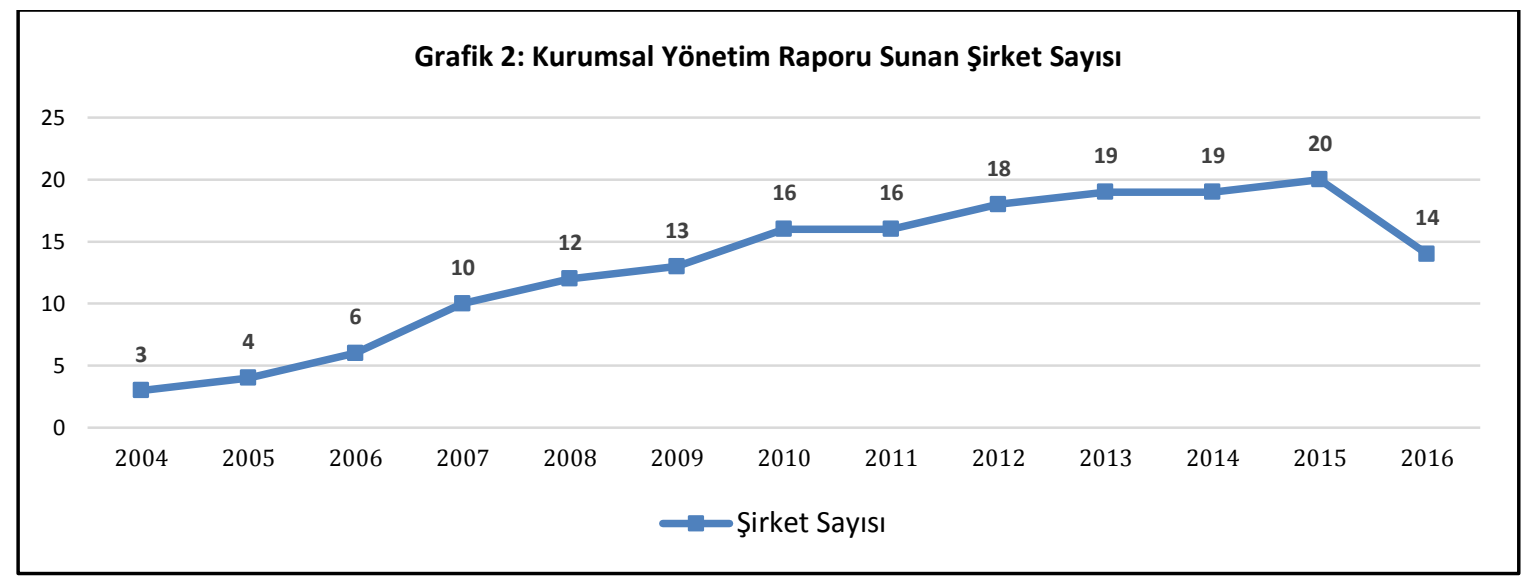

Kurumsal yönetim derecelendirme raporu sunan şirketlerin sayısı Grafik 3'te gösterilmiştir. Buna göre 2007 yılında 1 şirketin sunduğu rapor 2015 yılında gelindiğinde 15 şirket tarafından sunulmaya başlanmıştır.

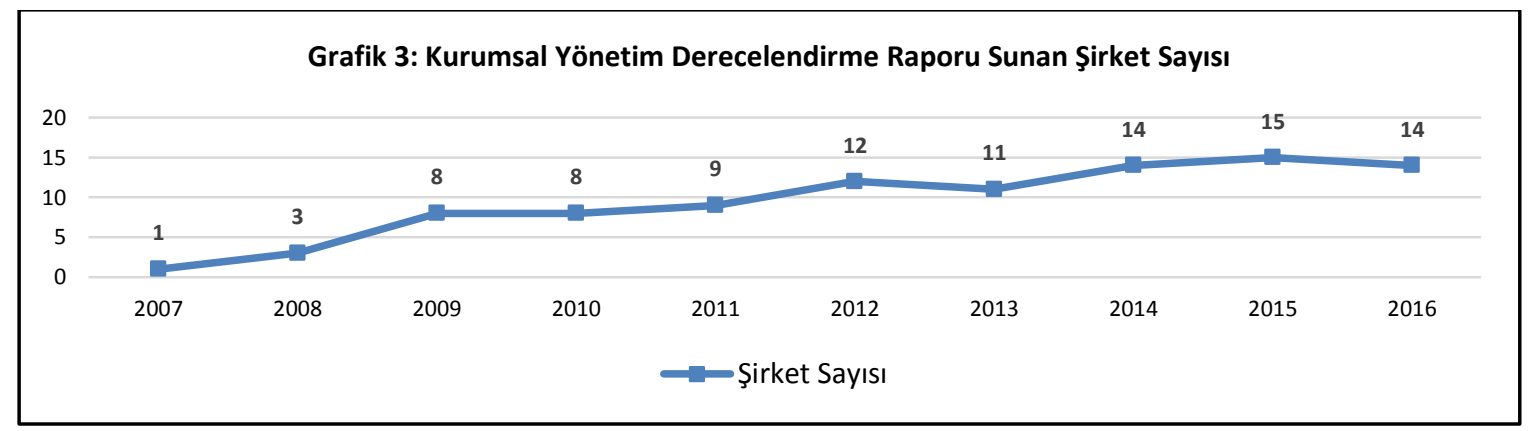

Sürdürebilirlik raporu sunan şirket sayısına ilişkin bilgiler Grafik 4’te gösterilmiştir. 2007 yılında 2 şirket tarafından sunulan rapor, özellikle 2013 yılından itibaren artış göstermeye başlamış ve 2015 yılında 21 şirkete kadar ulaşmıştır. Bununla birlikte BiST 30'daki tüm şirketler internet sitelerinde sürdürülebilirlik ile ilgili bilgi vermektedir.

Borsa İstanbul'da işlem gören ve kurumsal sürdürülebilirlik performansları üst seviyede olan şirketlerin yer aldığı BiST Sürdürülebilirlik Endeksi (XUSRD) bulunmaktadır. BIST 30 Endeksinde yer alan şirketlerden 23 tanesi aynı zamanda BIST Sürdürülebilirlik Endeksinde işlem görmektedir. Bu şirketlerden 19 tanesi sürdürülebilirliğe dair açıklamalara Sürdürülebilirlik Raporunda yer verirken Doğan Şirketler Grubu Holding A.Ş., Petkim Petrokimya Holding A.Ş. ve Türk Telekomünikasyon A.Ş. sürdürülebilirlik raporunu ayrıca sunmayıp bu bilgileri faaliyet raporları içinde açıklamışlardır. Tekfen Holding A.Ş. ise sürdürülebilirliğe ait bilgileri faaliyet raporu içinde dahi sunmamıştır.

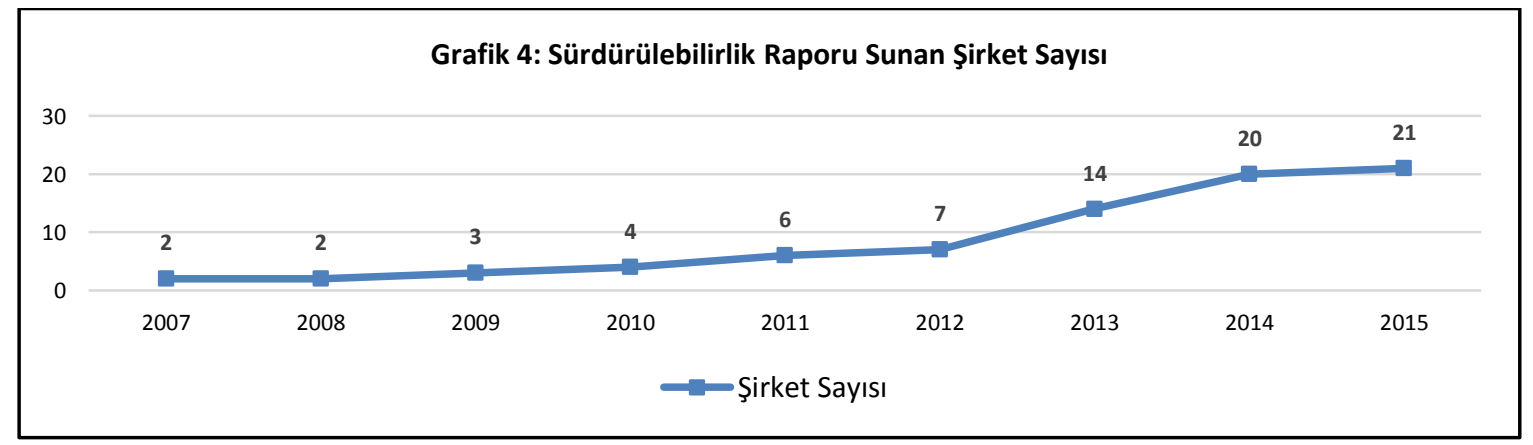

Faaliyet raporu, kurumsal yönetim raporu ve sürdürülebilirlik raporunu sunan şirket sayılarını yıllar itibari ile karşılaştırdığımızda Grafik 5'teki görünüm ortaya çıkmaktadır. Buna göre, tüm raporlarda yıllar itibari ile artış olmakla beraber faaliyet raporlarının hem daha erken hem de tüm şirketler tarafından sunulduğunu söylemek mümkündür. Daha sonra kurumsal yönetim raporlarının sunulmaya başlandığını, faaliyet raporları gibi tüm şirketler tarafından sunulmasa da önemli sayıdaki şirket tarafından sunulmaya başlandığı görülmektedir. Sürdürülebilirlik raporunun diğer raporlara göre daha yeni olduğunu gözükmektedir. Ancak özellikle 2013 yılından itibaren bu raporu sunan şirket sayısındaki artış ile birlikte 
kurumsal yönetim raporu sunun işletmelerden daha fazladır. Bunda kurumsal yönetime dair bilgileri faaliyet raporunda sunan işletmelerin bulunmasının da etkisi olabilir.

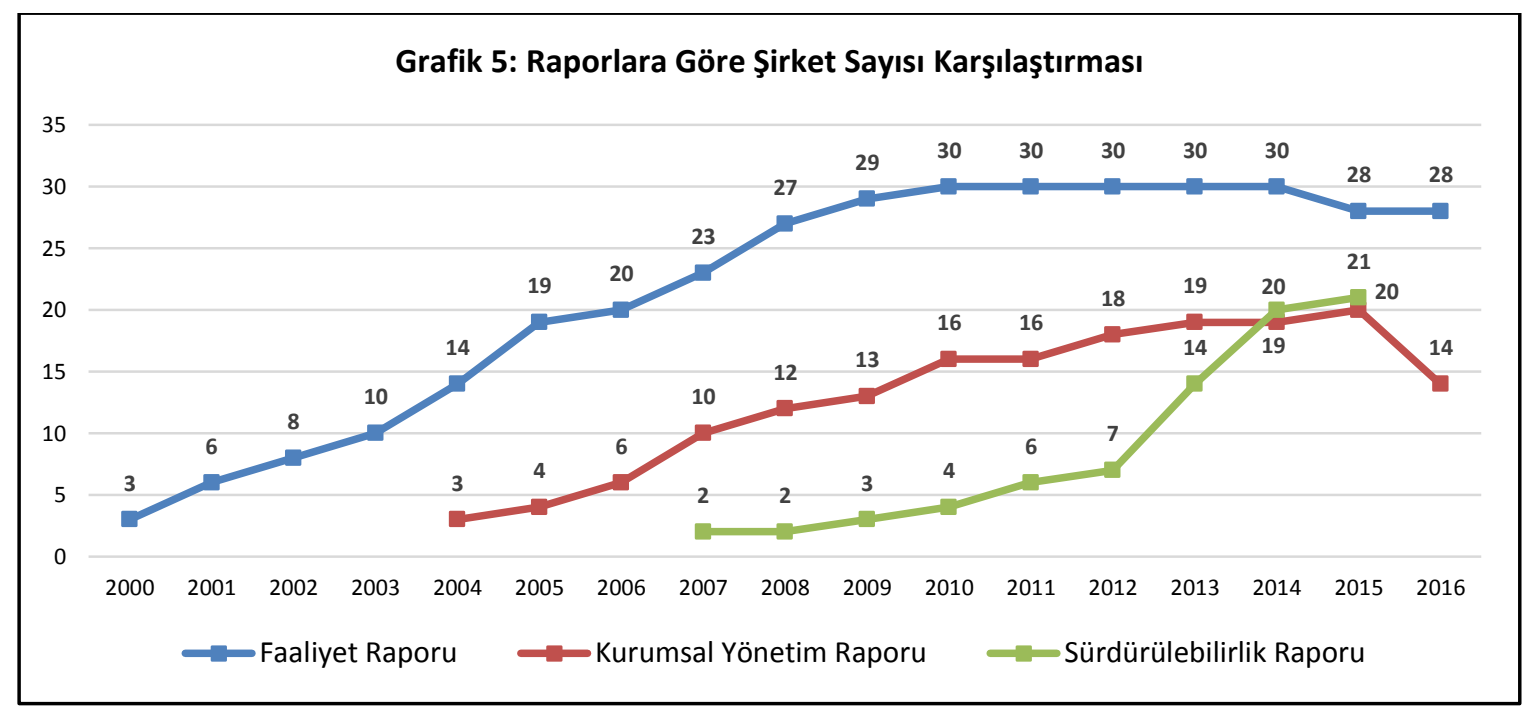

\section{SONUÇ}

Şirketler; doğru kararlar vermek, piyasa değerini arttırmak, paydaşlarını şeffaf bir şekilde bilgilendirmek, kredi sağlamak, yatırım çekebilmek ve benzeri nedenlerden hem şirket içindeki hem de şirket dışındaki paydaşlarına çeşitli raporlar sunmaktadırlar. Şirket dışına sunulan raporlar bir başka ifade ile kurumsal raporlar, başlangıçta sadece şirkete ait finansal bilgileri içeren raporlardan oluşmakta iken günümüze kadar olan tarihi seyir içinde değişkenlikler göstermiştir. Bu değişkenlikler de finansal bilgiler yanında finansal olmayan bilgileri de içeren kurumsal rapor türlerinin ortaya çıkmasına yol açmıştır. Bu ise paydaşların rakamlardan fazlasına ihtiyaç duymaları dolayısıyla bunu da talep etmelerinden ve artık değere yatırım yapmak istemlerinden kaynaklanmaktadır.

Şirketlerin yukarıda sayılan farklı rapor sunma nedenleri dışında şirket paydaşlarının talep ettikleri bilgi ihtiyacının farklılaşması, küreselleşme olgusu, yaşanan küresel ekonomik krizler ve şirket skandalları, getirilen yeni düzenlemeler ile yapılan uluslararası çevresel ve ticari anlaşmalar, şirketlerin bilgi paylaşımı ve kamuoyunu aydınlatma konusundaki karmaşıklığı önemli ölçüde arttırmıştır. Söz konusu karmaşıklık, şirketler tarafından sunulan farklı rapor türleri ile giderilmeye çalışılmaktadır. Bu çerçevede ortaya çıkan farklı kurumsal rapor türleri ise faaliyet raporları, kurumsal sosyal sorumluluk raporları, sürdürülebilirlik raporları ve entegre rapor gibi farkıı isimler altında sunulmaktadır.

Çalışmada öncelikle işletmelerin hazırladıkları raporlar hakkında çeşitli değerlendirmeler yapılmış olup raporlar, işletme içi raporlar (yönetim raporları) ve işletme dışı raporlar (kurumsal raporlar) olarak ikili sınıflandırmaya tabi tutulmuştur. Daha sonra ise kurumsal raporlara ağılık verilerek bunlar hakkında değerlendirilmelerde bulunulmuş ve bu raporların türleri hakkında bilgiler verilmiştir. Son olarak ise BiST 30'da yer alan şirketlerin hazırladıkları raporlar incelenmiş ve ortaya çıkan sonuçlar hakkında muhtelif değerlendirmelerde bulunulmuştur.

Hem incelenen rapor türleri hem de BIST 30'da gerçekleştirilen araştırma birlikte değerlendirildiğinde şunları ifade etmek mümkündür:

$\checkmark$ Rapor türleri, Türkiye'deki yasal düzenlemeler çerçevesinde değerlendirildiğinde bağımsız denetim, faaliyet ve kurumsal yönetim raporlarına ait çeşitli yasal düzenlemelerin bulunduğu ancak sürdürülebilirlik ve entegre rapor konusunda herhangi bir yasal düzenlemenin olmadığı görülmektedir.

$\checkmark$ Rapor türlerinin bazılarının yayımlanması yasal zorunluluktan kaynaklanmakta iken bazılarının yayımlanması işletme inisiyatifindedir. Ancak paydaşlar ile iletişiminde önemli bir araç olarak yer alan raporlar zorunlu olmasalar da işletmeler, paydaşları ile ilişkilerini sağlam tutmak adına bu raporları gönüllü olarak yayımlama eğilimindedirler.

$\checkmark$ BIST 30'da yer alan şirketlerden hiçbiri çalışmanın yapıldığı tarih itibariyle entegre rapor yayımlanmamıştır. 


\section{KAYNAKÇA}

Aerts, W., Peter, W. (2013). Global Financial Accounting and Reporting: Principles and Analysis, Hampshire: Cengage Learning.

Akbulut, A., (2013). Finansal Tabloları Bağımsız Denetime Hazırlama Kılavuzu. İstanbul: Maliye Hesap Uzmanları Derneği.

Aydın, S., (2015). Kurumsal Raporlamanın Evrilme Sürecine İlişkin Bir İrdeleme. Mali Çözüm Dergisi, cilt. 25, sayı. 130, s. 67-78.

Aydın, S., (2016). Kurumsal Sosyal Ve Çevresel Raporlama Performansının Ölçülmesi İçin Bir Modelleme Yaklaşımı. Muhasebe ve Denetime Bakış, cilt. 16, sayı. 49, s. 103-112.

BisT, (2014). Şirketler için Sürdürülebilirlik Rehberi.

Bozkurt, N., (2012). Muhasebe Denetimi. İstanbul: Alfa Yayınları.

Brockett, A., Rezaee, Z. (2012). Corporate Sustainability: Integrating Performance and Reporting. New Jersey: John Wiley \& Sons, Inc.

Cavlak, H., (2015). Uluslararası Finansal Raporlama Standartları ve Kurumsal Yönetim Iliş̧kisi: Kurumsal Yönetim Endeksi'ne Tabi Şirketlerde Bir Anket Çalışması. Marmara Üniversitesi SBE Yüksek Lisans Tezi.

Cebeci, Y., (2014). Finansal Tablolar Analizi Açısından Türkiye Finansal Raporlama Standartları (TFRS) Kapsamında Düzenlenen Finansal Tablolar ile Muhasebe Sistemi Uygulama Genel Tebliği'ndeki (MSUGT) Finansal Tabloların Karşılaştırılması. Marmara Üniversitesi SBE Yüksek Lisans Tezi.

Cömert, N., Kurt, S. (2014). Muhasebeci Gözüyle Kurumsal Sürdürülebilirlikte Yenilikler, Gelişmeler ve Ülke Uygulamaları. 13. Ulusal İşletmecilik Kongresi Bildiriler Kitabı, Cilt:2. İstanbul: Marmara Üniversitesi Yayınevi.

Çalış, Y. E., Altınsoy, N. B. (2014). Yönetim Raporlama Sisteminde Sorumluluk Muhasebesi: Bir İnşaat İşletmesinin Maliyet Merkezine Yönelik Performans Analizi. Afyon Kocatepe Üniversitesi IiBF Dergisi, cilt. 16, sayı. 1, s. 29-44.

Çalışkan, A. Ö., Güler, H. (2013). Şeffaflık ve Kamuyu Aydınlatma Ekseninde Internette Finansal Raporlama. Mali Çözüm Dergisi, sayı. 116, s. 57-84.

Deloitte ve TKYD., (2014). Anonim ve Limited Şirketler İçin Yıllık Faaliyet Raporu Hazırlama Kılavuzu. İstanbul: Deloitte Türkiye.

Doğan, M., (2007). Kurumsal Yönetim, Ankara: Siyasal Kitabevi.

Eccles, R. G., Serafeim, G. (2014). Corporate and Integrated Reporting: A Functional Perspective. Harvard Business School Working Paper, s. 14-094.

Eccles, R. G., Krzus, M. P., Ribot, S. (2015). The Integrated Reporting Movement. New Jersey: John Wiley \& Sons, Inc.

FEE., (2015). The Future of Corporate Reporting - Creating the Dynamics for Change.

Gençoğlu, Ü. G., Aytaç , A. (2016). Kurumsal Sürdürülebilirlik Açısından Entegre Raporlamanın Önemi ve BiST Uygulamaları, Muhasebe ve Finansman Dergisi, sayı. 72, s. 51-66.

Gökçen, G., Ataman, B., Çakıcı, C. (2016). Türkiye Finansal Raporlama Standartları Uygulamaları. İstanbul: Beta Basım.

Gökten, S., (2016). Entegre Raporlama Yaklaşımı İçin Uygulamaya Yönelik Sistematik Bir Öneri. Muhasebe Bilim Dünyası Dergisi, cilt. 18, sayı. 4, s. 741-765.

GRI. (2014). G4 Sürdürülebilirlik Raporlaması Kılavuzları.

Güvemli, B., Yaz, D. A., Aydın, S. (2016). Mali Tabloların Çağdaşlaşması ve Sürdürülebilirlik Raporlamaları Karşısında Türk Muhasebe Düşüncesindeki Gelişmeler. Muhasebe ve Finans Tarihi Araştırmaları Dergisi, sayı. 11, s. 169-196.

ICAEW. (2011). Developments in New Reporting Models: Information for Better Markets Initiative. www.icaew.com/bettermarkets

IIRC. (2013). Uluslararası <ER> Çerçevesi. www.theiirc.org

Illingworth, D., (2004). New Reporting Models for Business: Who Needs Them?", Measuring Business Excellence, vol. 8, no. 2, s. $4-8$.

Karğın, S., Aracı, H., Aktaş, H. (2013). Entegre Raporlama: Yeni Bir Raporlama Perspektifi. Muhasebe ve Vergi Uygulamaları Dergisi, cilt. 6, sayı. 1, s. 27-46.

Katsikas, E., Rossi, F. M., Orelli, R. L.. (2017). Towards Integrated Reporting Accounting Change in the Public Sector. Cham: Springer.

KGK., (2017). BDS705 Bağımsız Denetçi Raporunda Olumlu Görüş Dışında Bir Görüş Verilmesi.

KPMG., (2013). The Future of Corporate Reporting: Towards a Common Vision.

Mio, C., (2016). Integrated Reporting: A New Accounting Disclosure (Ed. C. Mio). London: Palgrave Macmillan.

Özdemir, Z., Pamukçu, F. (2016). Kurumsal Sürdürülebilir Raporlama Sisteminin Borsa İstanbul Sürdürülebilirlik Endeksi Kapsamındaki İ̧ıletmelerde Analizi. Mali Çözüm Dergisi, sayı. 134, s. 13-35. 
Palea, V., (2013). Financial Reporting under IAS / IFRS: Theoretical Background and Capital Market Evidence - A European Perspective, Bern: Peter Lang.

Pamukçu, F., (2011). Finansal Raporlama ile Kamuyu Aydınlatma ve Şeffaflıkta Kurumsal Yönetimin Önemi. Muhasebe ve Finansman Dergisi. sayı. 50, s. 133-148.

Pound, J., (2002). Kurumsal Olarak Yönetilen Şirket Neler Sağlayabilir? Ahmet Kardam (Çev.), Kurumsal Şirket Yönetimi (Harvard Business Review Dergisinden Seçmeler). İstanbul: Türkiye Metal Sanayicileri Sendikası.

PwC, (2013). Integrated Reporting: Going Beyond the Financial Results.

Resmi Gazete, (2011). Kurumsal Yönetim Illkelerinin Belirlenmesine ve Uygulanmasına İlişkin Tebliğ. Sayı: 28158.

Resmi Gazete, (2012). Şirketlerin Yıllık Faaliyet Raporunun Asgari İçeriğinin Belirlenmesi Hakkında Yönetmelik. Sayı: 28395.

Resmi Gazete, (2011). Türk Ticaret Kanunu. Sayı: 27846.

Selimoğlu, S. K., Özbirecikli, M., Uzay, Ş., Uyar, S. (2015). Bağımsız Denetim (Türkiye Denetim Standartlarıyla Uyumlaştırılmış). Ankara: TÜRMOB Yayınları.

Sipahi, B., Arsoy, A. P. (2010). Finansal Raporlamada Yeni Yaklaşımlar. Öneri Dergisi, cilt. 9, sayı. 33, s. 51-57.

SPK, (2017). Bağımsız Denetim Faaliyeti. www.spk.gov.tr (Erişim: 24.04.2017)

TDK, (2017). Rapor. www.tdk.org.tr (Erişim: 11.04.2017)

TiSK, (2016). Herkes İ̧̧in Kurumsal Sosyal Sorumluluk Projesi: Türkiye Sürdürülebilirlik Raporlaması Ulusal İnceleme Raporu.

Topçu, M. K., Korkmaz, G. (2015). Entegre Raporlama: Kavramsal Bir İnceleme. Dokuz Eylül Üniversitesi Iktisadi ve İdari Bilimler Fakültesi Dergisi, cilt. 30, sayı. 1, s. 1-22.

Uyar, A., (2015). Kurumsal Raporlamanın Gelişimi ve Güncel Yaklaşımlar. Ankara: Gazi Kitabevi.

Vasquez, J. L. B., (2017). Siz Şirketlerinizi Nasıl Raporluyorsunuz? KPMG Gündem Kış 2017, sayı 28.

Watson, A., (2012). Making Investment Grade: The Future of Corporate Reporting (United Nations Environment Programme, Deloitte and the Centre for Corporate Governance in Africa) içinde Annual Reporting Needs to Account for More. Cape Town. Standard Bank.

Yalkın, Y. K., Demir, V. (2015). Yönetim Aracı Olarak İşletme Bütçeleri. Ankara: Nobel Akademik Yayınclık.

Yanık, S., Türker, İ. (2012). Sürdürülebilirlik ve Sosyal Sorumluluk Raporlamasındaki Gelişmeler (Tümleşik Raporlama). İstanbul Üniversitesi Siyasal Bilgiler Fakültesi Dergisi, sayı. 47, s. 291-308. 